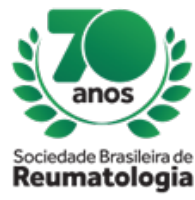

\title{
MALT LYMPHOMA MIMICKING GRANULOMATOSIS WITH POLYANGIITIS: A CASE REPORT
}

Luíza Sá e Rêgo Tupinambá (UNIFESP, SÃO PAULO, SP, Brasil), Luíza Sá e Rêgo Tupinambá (UNIFESP, SÃO PAULO, SP, Brasil), Mariana Davim Ferreira Gomes (UNIFESP, SAO PAULO, SP, Brasil), Mariana Davim Ferreira Gomes (UNIFESP, SAO PAULO, SP, Brasil), Igor Beltrão Duarte Fernandes (UNIFESP, sao paulo, SP, Brasil), Igor Beltrão Duarte Fernandes (UNIFESP, sao paulo, SP, Brasil), Germana Ribeiro Araújo Carneiro de Lucena (UNIFESP, sao paulo, SP, Brasil), Germana Ribeiro Araújo Carneiro de Lucena (UNIFESP, sao paulo, SP, Brasil), Renan Rodrigues Neves Ribeiro do Nascimento (UNIFESP, sao paulo, SP, Brasil), Renan Rodrigues Neves Ribeiro do Nascimento (UNIFESP, sao paulo, SP, Brasil), Daniel Viana da

Silva e Silva (UNIFESP, sao paulo, SP, Brasil), Daniel Viana da Silva e Silva (UNIFESP, sao paulo, SP, Brasil), Raquel Mitie Kanno (UNIFESP, sao paulo, SP, Brasil), Raquel Mitie Kanno (UNIFESP, sao paulo, SP, Brasil), Priscila Dias Cardoso Ribeiro (UNIFESP, sao paulo, SP, Brasil), Priscila Dias Cardoso Ribeiro (UNIFESP, sao paulo, SP, Brasil), Alexandre Lima Matos (UNIFESP, sao paulo, SP, Brasil), Alexandre Lima Matos (UNIFESP, sao paulo, SP, Brasil), Edgard Torres dos Reis Neto (UNIFESP, sao paulo, SP, Brasil), Edgard Torres dos Reis Neto (UNIFESP, sao paulo, SP, Brasil)

\section{BACKGROUND}

MALT lymphoma (mucosal associated lymphoid tissue) is a polymorphic disease defined as an extranodal lymphoma which symptoms vary according to the predominantly affected mucosal tissue. On the other hand, granulomatosis with polyangiitis (GPA) is an ANCA-associated vasculitis (AAV) characterized by the classic triad of necrotizing granulomatous inflammation in the upper respiratory tract, pulmonary nodules and necrotizing glomerulonephritis with possible involvement of other organs and systems, such as the skin. There are many reports of different types of lymphoma simulating or coursing with vasculitis, however this is the first case report of MALT lymphoma mimicking the clinical features of GPA.

\section{CASE REPORT}

a 38-year-old man, sought medical care with complaints of recurrent productive cough, fever and dyspnea for 4 years and, in the last two years, he noticed a progressive worsening of the symptoms, with daily fever of up to 39o Celsius, rhinorrhoea with blood splinters, associated with dyspnea on little exertions, weight loss of $20 \mathrm{~kg}$, fatigue and night sweats. In the meantime, he had several hospitalizations with treatment attempts with various antibiotic regimens including fungus and tuberculosis treatment without good response. He also had a medical history of peptic ulcer disease, a well-controlled asthma since childhood and a history of cocaine abuse 10 years ago. Then, he was referred to a tertiary medical center for further investigation. Upon admission, he had palpable cervical lymph nodes, rales in pulmonary bases, and a palpable purpuric rash on the lower limbs. A computed tomographic (CT) scan showed chronic pansinusopathy and the thoracic CT revealed consolidations with air bronchograms associated with multiple bilateral ground glass opacities, peribroncovascular thickening and mediastinal lymph node enlargement. ANCA test was negative. Biopsy of the skin lesions revealed leukocytoclastic vasculitis. A transbronchial biopsy was performed and the anatomopathological and immunohistochemistry analysis revealed a monomorphic lymphoid cell infiltrate with proliferation of low-grade lymphoid tissue, with predominance of non-germinal center type B immunophenotype, favoring mucosa-associated lymphoid tissue (MALT). The patient received glucocorticoids with complete resolution of the purpura and partial improvement of the systemic and respiratory symptoms. Then, he was referred to a Hematologic center to treat the underlying malignancy.

\section{CONCLUSION}


this report reveals the importance of the differential diagnosis between VAA and malignancies, since they are systemic diseases with multiple forms of presentation. Furthermore, illustrates that the histological analysis may be essential, since the clinical signs may not contain sufficient discriminatory elements. 